\title{
Determination of the Antagonistic Effects of Some Rhizospheric Bacteria against Macrophomina phaseolina under In Vitro Conditions ${ }^{\#}$
}

\author{
Özden Salman',a,*, Fatma Rana Bayram²,b, Nuh Boyraz ${ }^{1, c}$, Raziye Koçak ${ }^{3, d}$ \\ ${ }^{I}$ Department of Plant Protection, Faculty of Agriculture, Selçuk University, 42250 Konya, Turkey \\ ${ }^{2}$ Safa Agriculture Joint Stock Company, 42250 Konya, Turkey \\ ${ }^{3}$ Animal and Plant Production Department, Çumra Vocational School, Selçuk University, 42500 Konya, Turkey \\ *Corresponding author

\begin{tabular}{|c|c|}
\hline R T I C LE I N & TRA $\mathrm{C} T$ \\
\hline $\begin{array}{l}\text { \#This study was presented as an online } \\
\text { presentation at the } 2^{\text {nd }} \text { International } \\
\text { Oournal of Agriculture-Food Science } \\
\text { and Technology (TURJAF 2021) } \\
\text { Gazimağusa/Cyprus } \\
\text { Research Article } \\
\text { Received : 23/11/2021 } \\
\text { Accepted : 30/12/2021 } \\
\text { Keywords: } \\
\text { Macrophomina } \\
\text { Antibiosis } \\
\text { Bacillus } \\
\text { Bioagent } \\
\text { Charcoal rot }\end{array}$ & $\begin{array}{l}\text { Macrophomina phaseolina (Tassi) Goid. is a fungal pathogen causes charcoal rot disease (Sin: } \\
\text { Rhizoctonia bataticola) and is responsible for significant yield losses in many plants. In our study, } \\
\text { we aimed to evaluate the antagonistic ability of } 39 \text { different bacteria, isolated from the fields of } \\
\text { sugar beet in } 2019 \text {, against the pathogen Macrophomina phaseolina isolated from sugar beet, beans } \\
\text { and chickpeas. Approximately } 31 \% \text { of the bacteria showed antibiosis effect against the pathogen. It } \\
\text { was determined that the effectiveness level of Lelliottia amnigena, Bacillus atrophaeus, B.pumilus } \\
\text { and B. cereus ( } 7 \text { isolates) was moderate to high against Macrophomina phaseolina. Bacillus } \\
\text { atrophaeus (PTol5-1a) showed the highest efficacy of } 80 \% \text {, 72.94\% and } 82.35 \% \text { against } \\
\text { Macrophomina phaseolina of chickpea, bean and sugar beet respectively. Lelliottia amnigena (Pto } \\
14-1 b \text { ) was moderately effective ( } 57.78 \% \text { ) against the chickpea isolate of the pathogen. It was } \\
\text { observed that of the seven Bacillus cereus isolates used in the experiment, three isolates (Ptol4-1a, } \\
\text { Ptol2-1b, Ptol7-1b) were highly effective against the chickpea pathogen, two (Ptol2-1b, Ptol4- } \\
2 b \text { ) against bean pathogen, and one (Ptol5-1b) against sugar beet isolate. Results have shown varied } \\
\text { level of antagonism by different test bacterial against different Macrophomina phaseolina isolates, } \\
\text { while the highest level of antibiosis shown by Bacillus atrophaeus against all pathogenic isolates } \\
\text { indicated that it can be a potential future bioagent in managing the disease. }\end{array}$ \\
\hline
\end{tabular}

azdensalman@selcuk.edu.tr

nboyraz@selcuk.edu.tr (i) http://orcid.org/0000-0002-7871-4105
(i) http://orcid.org/0000-0001-6822-9360

b@fatmarana64@gmail.com rkocak@selcuk.edu.tr http://orcid.org/0000-0002-4530-9496

http://orcid.org/0000-0002-8221-0452

\section{Introduction}

Macrophomina phaseolina (Tassi) Goid. (Sin: Rhizoctonia bataticola) is a soil-borne polyphage pathogen which causes disease in more than 500 plant species from 100 different families (Jana et al., 2003). The name charcoal rot is given to the disease due to the development of charcoal like color in the infected plant tissues.

In Turkey, M. phaseolina was first reported in cotton, anise, sesame, tobacco, potato, pepper and eggplant in Izmir and Ankara (Korkom and Yıld1z, 2020). Studies carried out in recent years have suggested that this pathogen is posing an increasing threat to crop production (Ganeshamoorthi and Dubey, 2013; Khan et al, 2012; Lakhran et al., 2018; Leyva et al., 2019; Prasad et al., 2014; Sharma et al., 2012). It has been reported that dry root rot caused by this pathogen limits the production of host plants, especially in arid conditions (Sharma et al., 2010). Depending on the soil moisture, it can infect plants in a wide temperature range, from $20^{\circ} \mathrm{C}$ to $35^{\circ} \mathrm{C}$ (Nagasubramanian et al., 2018). It is common in temperate and arid regions of the world, especially in areas with high temperature and low precipitation, and can survive in the soil for a long time (2-15 years) with the microsclerotia it forms. The pathogen can be transmitted by seed and soil (agricultural instruments, irrigation water, animals and soil carried by the wind) and spends the winter as sclerot or pycnidium in plant residues or seeds in contaminated soil (Baird et al., 2003). Symptoms are generally seen during the late flowering and capsular bonding periods of the plant, and the infected plants are completely dry. In the root system of infected plants, there is an intense root rot that causes the reduction of lateral roots, especially small pinhead-sized microsclerotia on the root collar and stem along the roots (Pande et al., 2004). 
Difficulties in managing the soil-borne pathogens result in great economic losses. Soil disinfection and seed treatment are recommended in chemical control, but it only provides short-term protection against the pathogen. Therefore, the use of biological control agents against soilborne pathogens is becoming popular as an alternative to synthetic chemicals along with the development of resistant varieties. Application of some biological control agents such as Trichoderma spp., Bacillus spp., and Pseudomonas spp. in combination with solarization in small production areas is one of the alternative control methods (Elmore et al., 1997; Subbarao et al., 1999).

Bacillus spp. are widely used in the control of plant diseases and have been defined as potent antagonists against Macrophomina phaseolina (Singh et al., 2008; Cawoy et al., 2011). The mode of action of these antagonistic microorganisms include the induction of defense systems including mycoparasitism, production of antibiotics and secondary metabolites, competition for space and nutrients, and induction of systemic resistance in the plants (Howell, 2003; Benitez et al., 2010). In addition, since Bacillus species are considered plant growthpromoting rhizobacteria (PGPR), they can colonize plant roots and increase the growth and yield of plants (Sturz et al., 2000; Welbaum et al., 2004; Harman, 2006). Bacillus spp, which is environmentally friendly and among the most commercialized species, contributes to sustainable agriculture by providing a $40 \%$ increase in product yield (El-Akhdar et al., 2020). Bacillus subtilis effectively reduced the sclerotia germination of $M$. phaseolina in chickpea and was determined to be a potential candidate for biological control against root rot (Ahamad and Srivastava, 2000). In in vitro trials, P12 strain of Bacillus spp. inhibited $M$. phaseolina in beans and reduced the pathogen growth between $55 \%$ and $70 \%$ (Sabaté et al., 2020). Bacillus subtilis subsp. subtilis and $B$. amyloliquefaciens exhibited a high inhibitory effect (over $50 \%$ ) against three different strains of Macrophomina phaseolina (Torres et al., 2016). In a dual culture experiment, Bacillus spp. had a $43 \%$ effect on colony growth of Macrophomina phaseolina isolated from the strawberry plant. In addition, the application of the bioagent as root immersion reduced the severity and progression of Macrophomina phaseolina charcoal rot under controlled and field conditions (Pastrana et al., 2016). Kumar et al. 2020 reported complete inhibition of mycelial growth of $M$. phaseolina by Bacillus cereus at different concentrations under in vitro conditions.

The antagonistic activities of vermicompost were investigated under in vitro conditions against Sclerotinia sclerotiorum, Macrophomina phaseolina, Botrytis cinerea, and Verticilium dahliae. Among the potential antagonistic bacterial isolates, 28 isolates inhibited the development of M. phaseolina in dual culture assay at varying rates ranging between $1.67 \%-65.83 \%$, the majority of which belonged to Bacillus spp. Further experiments indicated that Bacillus pumilus was most effective $(65.83 \%)$ in inhibiting the mycelial growth of $M$. phaseolina (Soylu et al., 2019).

Therefore, the aim of this study was to determine the antagonistic effects of bacteria isolated from soil samples taken from Ilgin district of Konya against $M$. phaseolina isolates under in vitro conditions.

\section{Material and Method}

Material
Macrophomina phaseolina isolates used in the
experiment
Three different isolates of the pathogen Macrophomina phaseolina, isolated from sugar beet, chickpea and bean plants, tested for pathogenicity in previous studies, were obtained from the culture collection of Selçuk University Mycology Laboratory.

Bioagent Bacteria Used in Experiment

In this study, bacteria isolated from soil samples taken from the rhizosphere region of sugar beet plants in IlginKonya in 2019 and were diagnosed by MALDI-TOF biotyping were used as bioagents.

\section{Method}

Reproduction and inoculum preparation of Macrophomina phaseolina isolates

Toothpick from the previously-stored slant agar of respective pathogenic cultures was placed onto the PDA medium containing antibiotic (Streptomycin sulfate) in order to obtain the fresh pathogenic cultures. The petri dishes were then incubated at $23-25^{\circ} \mathrm{C}$ for 7 days.

Isolation and identification of bioagent bacteria

Isolation of beneficial bacterial agents from the soil samples was done according to Saygilı et al. (2006) and the petri dishes were incubated at $27^{\circ} \mathrm{C}$ for $24-48$ hours. Pure cultures were obtained by streaking the single bacterial colonies with different growth patterns followed by an incubation period as mentioned earlier. The pure cultures were stored in $30 \%$ glycerol at $-20^{\circ} \mathrm{C}$.

Determination of antibiosis effect

In order to determine the antibiosis effects, 7 days old cultures of Macrophomina phaseolina and biocontrol agents incubated for 24-48 hours were used. Intensive PDA medium without antibiotics was used as the medium. An agar disk taken from the pathogen is placed in the middle of the $9 \mathrm{~cm}$ petri dishes. Then, a loopful of bacteria was streaked around the agar disk in the middle of the petri dish with a $3 \mathrm{~cm}$ diameter circle. Control petri dishes only contained the pathogen. After 7 days, the mycelial growth of the pathogen was measured with the help of a ruler. Antifungal activity of bacteria against the fungus was measured using following formula;

$$
\text { Inhibition }(\%)=\frac{\mathrm{A} 1-\mathrm{A} 2}{\mathrm{~A} 1} \times 100
$$

A1= Mycelial growth (control),

A2 = Mycelial growth (treatment) (Tariq et al., 2010).

Potential bioagents effective on all 3 isolates were sent to Hatay Mustafa Kemal University Plant Health Application and Research Center for diagnosis through MALDI-TOF biotyping.

\section{Results and Discussion}

In this study, a total of 39 rhizospheric bacterial isolates were tested for their potential antibiosis effect against Macrophomina phaseolina. Twelve of these bacteria showed antagonistic effects at different levels (17.64\%- 
82.35\%) against the pathogen. Results of MALDI-TOF MS biotyping diagnosis identified these bacterial species as Lelliottia amnigena, Bacillus atrophaeus, B. pumilus, and B. cereus (7 isolates). Bacterial species, isolate codes, $\%$ effectiveness against the pathogen isolated from different hosts is given in Table 1 .

Table 1. Bacteria used in the experiment and \% effects of bacteria against Macrophomina phaseolina isolates

\begin{tabular}{l|lccc}
\hline \multirow{2}{*}{ Antagonistic Bacteria } & \multicolumn{2}{c}{ Code of Antagonist } & \multicolumn{2}{c}{ Effect on Macrophomina phaseolina Isolates (\%) } \\
\cline { 2 - 5 } Lelliottia amnigena & Isolates & Chickpea & Bean & Sugar Beet \\
B. atrophaeus & Pto14-1b & $57.78^{* *}$ & - & - \\
- & Pto15-1a & $80^{* * *}$ & $72.94 * * *$ & $82.35^{* * *}$ \\
B.pumilus & Pto16-1 & $32.22^{*}$ & $17.64^{*}$ & - \\
\hline & PTo13-1cb & $60^{* *}$ & - & $33.33^{*}$ \\
\hline \multirow{5}{*}{ B. cereus } & Pto14-1a & $65.56^{* * *}$ & $58.82^{* *}$ & $64.44^{* *}$ \\
& PTo12-1b & $67.78^{* * *}$ & $72.94^{* * *}$ & $35.29^{*}$ \\
& PTo14-2b & $64.44^{* *}$ & $68.89^{* * *}$ & $35.56^{*}$ \\
& Pto15-2b & - & $58.82^{* *}$ & - \\
& Pto15-1b & - & - & $61.11^{* * *}$ \\
\hline- & PTo17-2 & - & $58.82^{* *}$ & - \\
\hline
\end{tabular}

*Isolates with efficacy level below 50\%, **Moderate effectiveness, *** High level of effectiveness

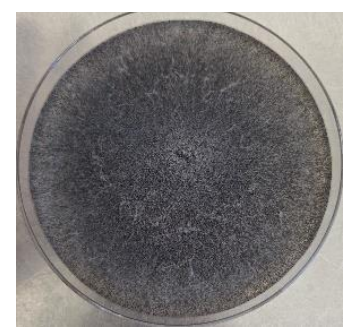

a

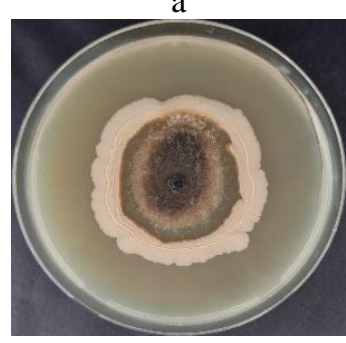

e

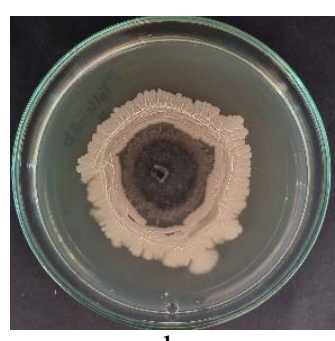

b

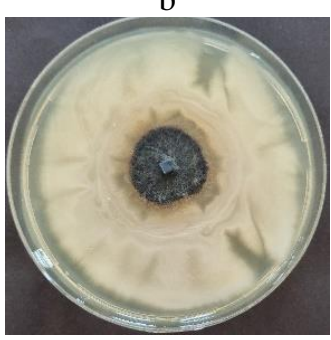

f

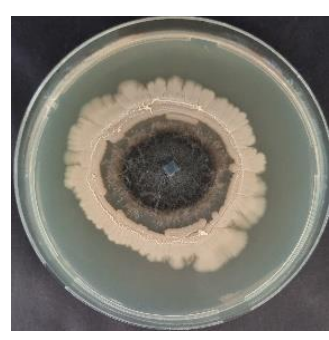

C

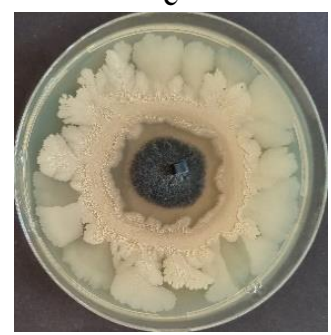

$\mathrm{g}$

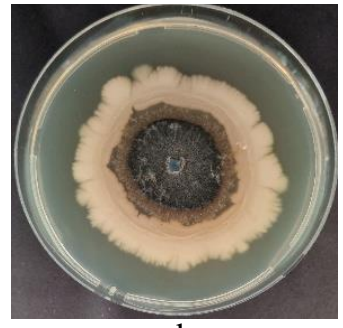

$\mathrm{d}$

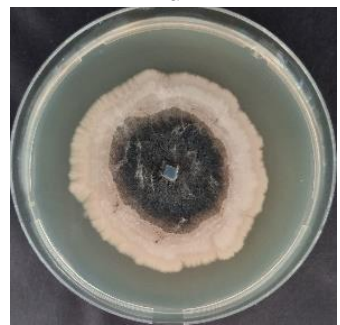

$\mathrm{h}$

Figure 1. The bacterial inhibitioin zones against Macrophomina phaseolina bean isolate; a-Control, b-Pto 14-2b, c-Pto 14 1a, d-Pto 17 1b, e-Pto 14 2b, f-Pto 12 lb, g-Pto 15 1a, h-Pto $152 b$.

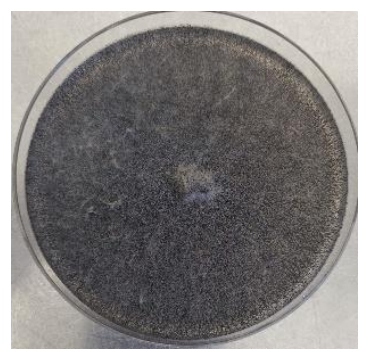

a

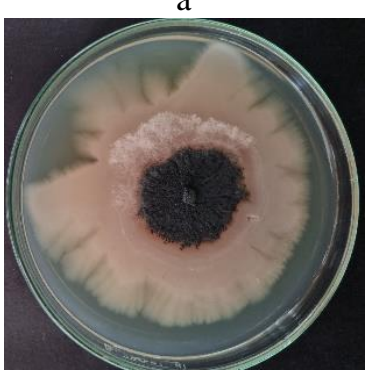

e

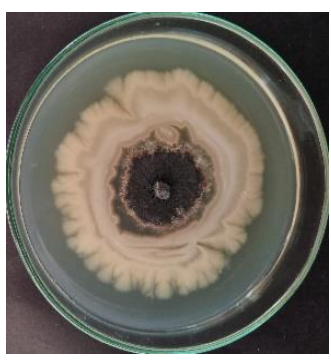

b

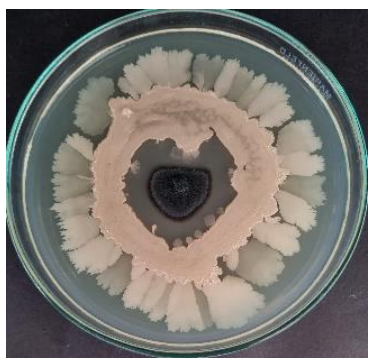

f

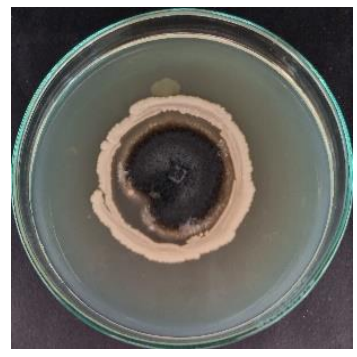

c

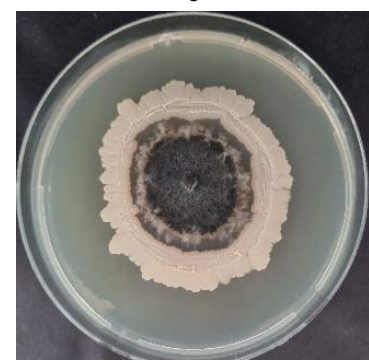

$\mathrm{g}$

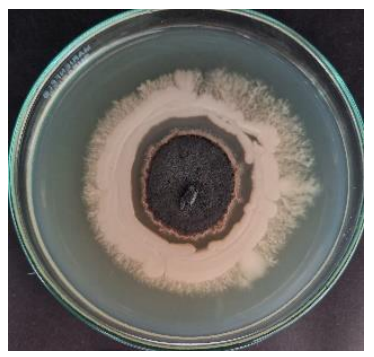

d

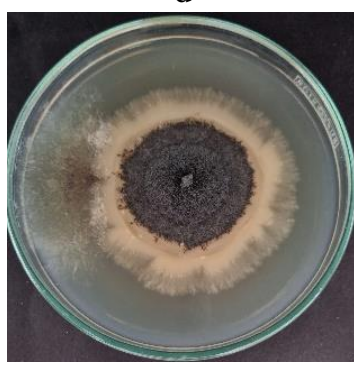

$\mathrm{h}$

Figure 2. The bacterial inhibitioin zones against Macrophomina phaseolina chickpea isolate; a-Control, b-Pto $121 \mathrm{~b}, \mathrm{c}-$ Pto $13 \mathrm{cb}$, d-Pto 14 1a, e-Pto 14 2b, f-Pto 15 1a, g-Pto 17 1b, h-Pto 14 lb. 


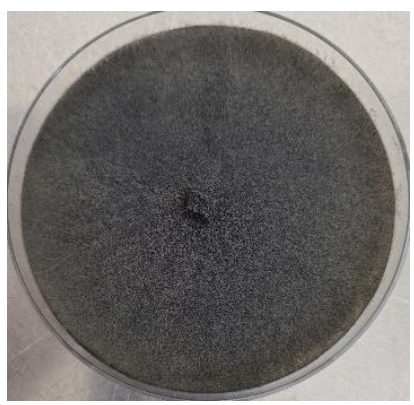

a

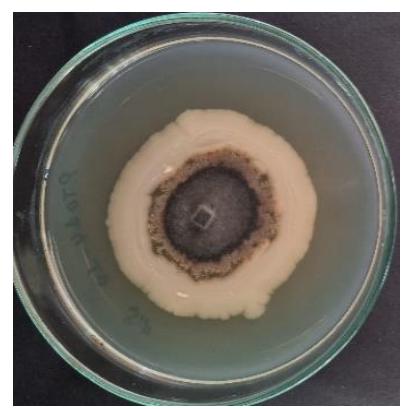

b

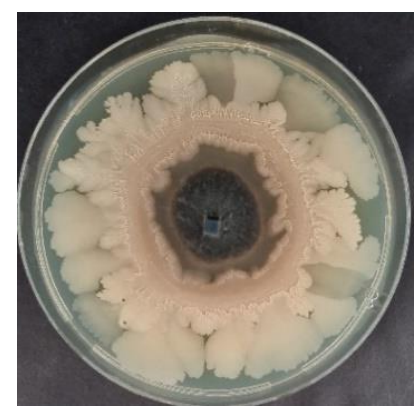

c

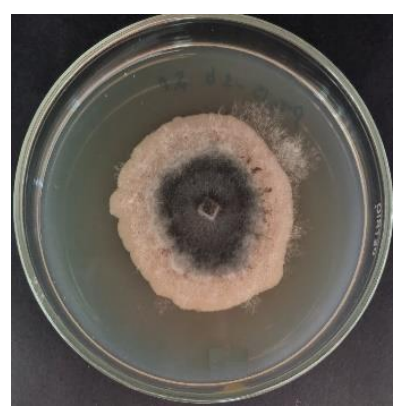

d

Figure 3 The bacterial inhibitioin zones against Macrophomina phaseolina sugar beet isolate; a-Control, b-Pto 14 1a, cPto 15 1a, d-Pto 15 1c.

According to the results of in vitro tests, it was observed that the bacterial isolates had different levels of antagonism against different isolates of the pathogen, while some bacteria was effective against only 1 or 2 isolates of the pathogen. Approximately $31 \%$ of the bacteria showed an antibiosis effect against the pathogen. Bacteria with 50$65 \%$ efficacy were considered as moderately effective, while $\geq 65 \%$ effective bacteria were considered as highly effective. Isolates Pto15-1a, Ptol4-1a, PTol2-1b, and PTo14-2b were effective against 3 isolates of the pathogen. PTol5-1a showed the highest antagonistic potential against Macrophomina phaseolina isolates of chickpea, bean, and sugarbeet with $80 \%, 72.94 \%$, and $82.35 \%$ activity, respectively. Eight bacterial isolates exhibited an antibiosis effect against the chickpea isolate of the pathogen, ranging between $32.22 \%-80 \%$ (Figure 2). Highly effective bacterial isolates were Ptol5-1a, Ptol4$1 a$, PTo12-1b, and Pto 17-1b, while Pto14-1b, PTo13-1cb, and $P$ Tol4- $2 b$ gave moderate results. Nine bacterial isolates were found to be effective (17.64\%-72.94\%) against the bean isolate of the pathogen, from which Pto 15 1a, PTo12-1b, PTo14-2b were highly effective while the moderate effectiveness was recorded for Pto14-1a, Pto152b, PTo17-2, and PTo17-1b (Figure 1). The data from the sugar beet isolate was different from the other isolates in the way that only one bacterial isolate, Pto15-1a, was found to be highly active against this isolate while Ptol4$1 a$ and Pto15-1b were determined to be moderately effective (Figure 3).

Bacterial isolates with moderate or high efficacy against at least one pathogen isolate were sent to Hatay Plant Health Clinic Research and Application Center to be identified. Bacterial strains identified by MALDITOF MS were; B. cereus (Pto14-1a, PTo12-1b, PTo14-2b, Pto152b, Pto15-1b, PTo17-2 and PTo17-1b), B. pumilus (PTo13-1cb), Lelliottia amnigena (Pto14-1b) and $B$. atrophaeus (Pto15-1a). Pto14-1b, determined as $L$. amnigena according to MALDI-TOF MS results, showed an antibiosis effect of $57.78 \%$ against the chickpea isolate of the pathogen. This bacterial species in our study has been previously used in different studies in terms of promoting plant growth in saline soils. A study revealed that Bacillus halotolerans MSR-H4 and Lelliottia amnigena MSR-M49 have great potential when evaluated in promoting wheat growth in saline soils and will offer a promising agricultural solution to increase crop yield in semi-arid regions (Liu et al., 2016; Al-Akhdar et al., 2020). In another study, the effects of 5 different bacterial isolates on the growth of wheat at 4 different salt concentrations were investigated in pot experiments. They reported that $L$. amnigena showed a positive effect on the development of wheat (Ateş and Kıvanç, 2020). The use of L. amnigena as a potential antifungal biocontrol agent has also been reported. In particular, strains that produce high levels of chitinase and protease have inhibited the growth of Fusarium spp. and Macrophomina phaseolina (Gohel et al., 2004). Despite many studies of its antagonistic abilities against plant pathogens, it is not considered suitable for use in biological control as it can cause infection in humans and also is responsible for soft rot of potatoes and onions (Abd Elhafeez et al., 2018).

Bacillus atrophaeus Pto15-1a showed highest antagonistic activity against all Macrophomina isolates in this study with $80 \%, 72.94 \%$ and $82.35 \%$ efficacy against the chickpea, bean and sugar beet isolates, respectively. Bacillus atrophaeus D8 was found to be $51.30 \%$ effective in in vitro inhibition of Macrophomina phaseolina CHP421 causal agent of charcoal rot of oilseed plants (Gözübüyük et al., 2021).

The bacterial isolate $P T o 13-1 c b$ was identified as Bacillus pumilus and exhibited $60 \%$ effectiveness against chickpea isolate and $33.33 \%$ against sugar beet isolate of M. phaseolina. It did not show an antagonistic activity against the bean isolate of the pathogen. Abd-El-Khair et al. (2016) tested 30 bacteria obtained from the rhizosphere region of healthy plants in a study on Macrophomina phaseolina and Rhizoctonia solani diseases in peanuts. The inhibition percentages of bacteria obtained against these 2 diseases were between $11.1 \%$ and $88.9 \%$. The isolates showing the strongest antagonistic effects in dual cultures of M. phaseolina and R. solani are Rb14 (Bacillus pumilus), $\mathrm{Rb} 18$ (Bacillus subtilis) and Rb28 (Bacillus subtilis). In in vivo pot experiments, $R b 14, R b 18$ and $R b$ 28 reduced the symptoms of damping off and root rot in infected soil infected compared to the control.

Pto14-1a, PTo12-1b, PTo14-2b, Pto15-2b, Pto15-1b, PTo17-2 and PTo17-1b isolates were determined as Bacillus cereus. Although there are studies about Bacillus cereus showing antagonistic properties against plant pathogens, there are almost no studies against Macrophomina phaseolina. In a study by Soylu et al. (2019), it was determined that Bacillus cereus BV-2e isolate caused darkening in S. sclerotiorum hyphae and suppressed the disease. B. cereus is known to cause local infections in wounds and eyes, septicemia, central nervous system infections including meningitis, respiratory tract infections, and toxin-induced syndromes in terms of human health (Drobniewski, 1993). When considered from 
this point of view, there are some concerns in the conversion of Bacillus cereus into biological preparations.

As a result of this research, we obtained different bacteria from different plant rhizospheres which we found effective against Macrophomina phaseolina. Although the reactions of these bacteria vary according to the pathogen, but a strong bacterial isolate such as Pto15-1 $a$ was acquired which produced the maximum inhibition zone against all pathogen isolates and the disease was suppressed. In the light of all these data obtained, it is important to evaluate Pto15-1 a in further research.

\section{References}

Abd Elhafeez AIKhazindar, E, Sayed ETA. 2018. Isolation and Characterization of Enterobacter Strains Causing Potato Soft Rot Disease in Egypt. Minia Science Bulletin, Botany section, 29(1): 1-13.

Ahamad S, Srivastava M. 2000. Biological control of dry root rot of chickpea with plant products and antagonistic microorganisms Ann. Agric. Res. 21: pp. 450-451.

Ateş Ö, Kıvanç M. 2020. Isolation of ACC Deaminase Producing Rhizobacteria from wheat rhizosphere and determinating of Plant Growth Activities Under Salt Stress Contiditions. Applied Ecology and Environmental Research. 18(4): 59976008.

Baird RE, Watson CE and Scruggs M. 2003. Relative longevity of Macrophomina phaseolina and associated mycobiota on residual soybean roots in soil. Plant Dis. 87: 563-566.

Benitez LB, Velho RV, Lisboa MP, Medina Costa da LF, Brandelli A. 2010. Isolation and characterization of antifungal peptides produced by Bacillus amyloliquefaciens LBM5006. J. Microbiol. 48(6): pp. 791-797.

Cawoy H, Wagner B, Fickers P and Ongena M. 2011. Bacillus Based Biological Control of Plant Diseases, Pesticides in the Modern World Pesticides Use and Management. Dr. Margarita Stoytcheva (Ed.). ISBN: 978-953-307-459-7.

Drobniewski FA. 1993. Bacillus cereus and Related Species. Clinical Microbiology Reviews. 6(4): 324-338.

Edmunds LK. 1964. Combined relation of plant maturity, temperature, and soil moisture to charcoal stalk rot development in grain sorghum. Phytopathology. 54: 514-517.

El-Akhdar I, Elsakhawy T, Abo-Koura Hanaa A. 2020. Alleviation of Salt Stress on Wheat (Triticum aestivum L.) by Plant Growth Promoting Bacteria strains Bacillus halotolerans MSR-H4 and Lelliottia amnigena MSR-M49. Journal of Advances in Microbiology. 20(1): 44-58.

Elmore CL, Stapleton JJ, Bell CE, Devay JE. 1997. Soil Solarization: A Nonpesticidal Method for Controlling Diseases, Nematodes, and Weeds. University of California Division of Agriculture and Natural Resources Publication 21377.

Ganeshamoorthi P, Dubey SC. 2013. Anastomosis grouping and genetic diversity analysis of Rhizoctonia solani isolates causing wet root rot in chickpea. Afr J Biotechnol. 12(43): 6159-6169.

Gohel V, Chaudhary T, Vyas P, Chhatpar HS. 2004. Isolation and identification of marine chitinolytic bacteria and their potential in antifungal biocontrol. Indian J Exp Biol, 42(7): 715-720.

Gözübüyük A, Can C, İşler Ceyhan D, Talapov T. 2021. Yağlı Tohumlu Bitkilerde Kömür Çürüklüğü Etmeni Macrophomina phaseolina'nın in vitro gelişimi üzerine Bacillus Türlerinin Etkinliğinin Belirlenmesi. Sözlü Sunum, 10. Uluslararası Bilimsel Araştırmalar Kongresi Fen ve Mühendislik Bilimleri. 11-12 Nisan 2021, Ankara.
Harman GE. 2006. Overview of mechanisms and uses of Trichoderma spp. Phytopathology. 96: 190-194.

Howell A, Dubrac S, Andersen KK, Noone D, Fert J, Msadek T and Devine K. 2003. Genes controlled by the essential YycG/YycF two-component system of Bacillus subtilis revealed through a novel hybrid regulator approach. Molecular Microbiology. 49: 1639-1655.

Jana T, Sharma T, Prasad RD and Arora DK. 2003. Molecular characterization of Macrophomina phaseolina and Fusarium species by a single primer RAPD technique. Microbiological Research. 158: 249-257.

Khan RA, Bhat TA, Kumar K. 2012. Management of chickpea (Cicer arietinum L.) dry root rot caused by Rhizoctonia bataticola (Taub.) Butler. International Journal of Research in Pharmaceutical and Biomedical Sciences. 3(4): 1539-1548.

Korkom Y, Yıldız A. 2020. Çilek Üretim Alanlarından İzole Edilen Trichoderma İzolatlarının Çilekte (cv. Rubygem) Macrophomina phaseolina 'ya Karşı Etkinliğinin Değerlendirilmesi. ADÜ Ziraat Derg. 17(1): 21-28. doi: 10.25308/aduziraat/619308.

Kumar KS, Sivakumar T, Saravanan KR, Balabaskar P.and Sudhasha S. 2020. Efficacy of Seed Plus Soil application of Bacillus cereus on The Root Rot (Macrophomina Phaseolina (Tass1.) Go1d. ) Incidence And Plant Growth of Groundnut. Plant Archives. 20(1): pp. 1217-1221.

Lakhran L, Ahir RR, Choudhary M, Choudhary S. 2018. Isolation, purification, identification and pathogenicity of Macrophomina phaseolina (Tassi) goid caused dry root rot of chickpea. Journal of Pharmacognosy and Phytochemistry.7(3): 3314-3317.

Leyva GAF, Gallegos JAA, Murrieta PFO, Valenzuela I.P, Bravo AA, Soto MR, Félix SV. 2019. Distribution of fungi associated with chickpea root rot. Revista mexicana de ciencias agrícolas. 10(1): 131-142.

Liu S, Tang Y, Wang D, Lin N and Zhou J. 2016. Identification and characterization of a new Enterobacter onion bulb decay caused by Lelliottia amnigena in China. Appl. Microbiol. 2:2.

Mihail JD, Rush CM (Eds). 1992. Macrophomina In: Singleton Methods for research on soilborne phytopathogenic fungi. St. Paul: The American Phytopathological Society. pp. 134-136.

Nagasubramanian K, Jones S, Sarkar S, Singh AK, Singh A, Ganapathysubramanian B. 2018 Hyperspectral band selection using genetic algorithm and support vector machines for early identification of charcoal rot disease in soybean stems. Plant Methods. 14:86. DOI: https://doi.org/10.1186/1300.

Pande S, Kishore GK, Rao JN. 2004. Evaluation of chickpea lines for resistance to dry root rot caused by Rhizoctonia.. International Chickpea and Pigeonpea Newsletter. 11(2): 3738.

Pastrana A, Basallote-Ureba M, Aguado A, Akdı K and Capote N. 2016. Biological control of strawberry soil-borne pathogens Macrophomina phaseolina and Fusarium solani, using Trichoderma asperellum and Bacillus spp. Phytopathologia mediterranea. 55(1): 109-120.

Prasad J, Gaur VK, Mehta S. 2014. Pathogenicity and characterization of Rhizoctonia solani Kühn Inciting wet root rot in chickpea. The Journal of Rural and Agricultural Research. 14(1): 12-14.

Sabaté DC, Petroselli G, Erra-Balsells R, Carina Audisio M, Brandan CP. 2020. Beneficial effect of Bacillus sp. P12 on soil biological activities and pathogen control in common bean. Biological Control. Volume 141. February 2020. Article 104131.

Saygılı H, Şahin F, Aysan A. 2006. Fitobakteriyoloji. Meta Basım Matbaacilik Hizmetleri, Bornova, İzmir.

Sharma M, Mangla UN, Krishnamurthy M, Vedez V, Pande S. 2010. Drought and dry root rot of chickpea. Paper presented in 5 th International Food Legumes Research Conference (IFLRCV) and European conference on Grain Legumes (AEP VII). April 26-30. 2010. Antalya, Turkey. 
Singh N, Pandey P, Dubey RC, Maheshwari DK. 2008. Biological control of root rot fungus Macrophomina phaseolina and growth enhancement of Pinus roxburghii (Sarg.) by rhizosphere competent Bacillus subtilis BN1. World Journal of Microbiology and Biotechnology, 24(9): pp. 1669-1679.

Soylu EM, Soylu S, Kara M, Kurt Ş. 2019. Sebzelerde sorun olan önemli bitki fungal hastalı etmenlerine karşı vermikomposttan izole edilen mikrobiyomların in vitro antagonistik etkilerinin belirlenmesi. KSÜ Tarım ve Doğa Dergisi. 23(1): 7-18.

Sturz AV, Christie BR and Nowak J. 2000. Bacterial endophytes: potential role in developing sustainable systems of crop production. Critical Reviews in Plant Sciences. 19: 1-30.
Subbarao KV, Hubbard JC, Koike ST. 1999. Evaluation of Broccoli Residue Incorporation Into Field Soil for Verticillium Wilt Control in Cauliflower. Plant Disease. 83(2): 124-129.

Tariq M, Yasmin S, Hafeez FY. 2010. Biological Control of Potato Black Scurf By Rhizosphere Associated Bacteria. Brazilian Journal of Microbiology. 41: 439-451.

Torres MJ, Pérez Brandan C, Petroselli G, Erra-Balsells R, Audisio MC. 2016. Antagonistic effects of Bacillus subtilis subsp. subtilis and B. amyloliquefaciens against Macrophomina phaseolina SEM study of fungal changes and UV-MALDI-TOF MS analysis of their bioactive compounds. Microbiological Research.182: pp. 31-39.

Welbaum G, Sturz AV, Dong Z and Nowak J. 2004. Fertiliz- ing soil microorganisms to improve productivity of agroecosystems. Critical Review in Plant Sciences. 23: 175-193. 